\title{
Response of University Library Management to Changing Modes of University Governance and Control
}

If I were founding a university I would found first a smoking room; then when I had a little more money in hand I would found a dormitory; then after that, or more probably with it, a decent reading room and a library. After that, if I still had more money that I couldn't use, I would hire a professor and get some textbooks.

-Stephen Leacock, Oxford As I See It

I

BEGIN WITH THIS QUOTATION from Stephen Leacock not to deliver some kind of an attention-getting psychic shock to my auditors-(for you will note that Leacock places libraries in the campus pecking order somewhere between the smoking room and textbooks)but rather to call attention to the fact that in his listing of priorities administrators do not "make the team" at all. This delightful British approach regarding the importance of administrators may exist in our moments of wishfulfillment on our own campuses, but in fact the top administrators in our institutions of higher education have enormous influence in all aspects of campus

This paper was presented at the Seventyeighth meeting of the Association of Research Libraries held in Colorado Springs, Colorado, May 14-15, 1971, by Earl C. Bolton, Vice President of the Institutional Management Division of Booz, Allen and Hamilton, Inc. life including our libraries.

My remarks are intended to explore changing patterns in campus finance and administration and to investigate the interaction between the central campus administration and the library administration. To do this, I am going to have to engage in one of mankind's most hazardous activities-predicting the future. I am willing to undertake this foolhardy enterprise because of the courageous example set by those who selected the theme for this conference, "The University Library in the Seventies," and assigned the many anticipatory and prospective subjects which we will be discussing today and tomorrow.

For nearly thirty years as student, graduate student, faculty member and administrator, I have been attending various academic meetings, conferences and conventions. As we all know, these often are centered around the status quo, some recently concluded project of interest, the history of some worthwhile effort or the whipping of a dead horse. Although it is indeed much safer to whip a dead horse than to try to tame a live one, I heartily commend those who assigned to this conference a forwardlooking orientation and hope that, by the time we go our separate ways Sunday, we all have some slightly better insights into how to deal with what may turn out to be the Schizophrenic Seventies.

In reminiscing about the $1960 \mathrm{~s}$ in higher education in this country, I think 


\section{6 / College \& Research Libraries • July 1972}

it is fair to characterize that decade as a time of:

Great growth and expansion, Application of confrontational tactics to the campus and to campus issues, Relative affluence, and

Growing disenchantment in the minds of some donors, legislators, voters, and the "general public" (if there is such a thing) regarding the role and operations of colleges and universities.

What will be the main trends on the campuses during the 1970s? If we could meet together here in 1981, what are the labels which we might attribute to this decade? All planning is based on some assumptions about the nature of our future environment, and I suggest that if we continue to speculate throughout this meeting regarding future trends, we will have the best chance of devising effective professional responses for the seventies. As one popular comedian says, "The future lies ahead." So let's take a look at it even though we know at the start that our guesses will be only partially accurate and will need constant readjustment with each passing year.

I suggest that the 1970s will be for higher education a time of:

Financial distress and relatively inadequate funding,

New modes of organization and administration, and

New roles for the library and the librarian.

Let us look at each of these predictions separately and explore their impact upon research libraries and the executives who are responsible for their effective operation.

\section{Financial Distress and Relatively INADEQUATE FUNDING}

A very melancholy scenario has been repeating itself on our college and university campuses during the last few years. A few months before the end of the fiscal year, the chief fiscal officer goes to the chief executive and says: "It looks as if we're going to have a deficit Mr. President (Chancellor)." The chief administrative officer, of course, asks: "How much?" The chief fiscal officer says, in effect, that he is not sure, that the available data are not adequate for a considered prediction and adds that everything of course will be done to keep the deficit to a minimum. About two months after the close of the fiscal year, the president returns from lunch one day to find his office crowded with several of his colleagues-the chief fiscal officer, the treasurer, the business manager, the budget director, the chief accountant, and others. The message is that the deficit was several times that which had been anticipated, and that it looks as if the year just beginning will be even worse.

At this point, the chief executive rapidly reaches several conclusions:

The fiscal reports he had been receiving have not been sufficiently timely or detailed for effective decision-making;

$\mathrm{He}$ is going to have to curtail spending dramatically and look for new sources of revenue; and

He had better call up the chairman of the governing board and the chairman of the finance committee immediately because the next board meeting is likely to be quite animated.

As the president looks through the budget to determine where he can make savings, he is more likely than not to come up with one or all of the following questions:

Can't the maintenance we had been planning for the library be deferred?

Can't the library operate with a smaller and less expensive staff?

Can't the acquisition of some of the books and periodicals which the li- 
brarian says he needs be postponed until next year?

Why haven't we worked out some kind of a regional arrangement with the other libraries in the area? Whatever became of that idea of central cataloging? I wonder how much we are losing because of theft from the library each year?

I do not mean to suggest that the chief executive officer is going to single out the library for particularly harsh treatment, but I do mean that the library budget at every institution is always sufficiently large to attract attention, and that the president at least begins with the idea that perhaps there are fewer people with "tenure" and "security of employment" in the library than in many other areas of the university. He will ask himself:

How can I justify continued growth of the library if all other parts of the university are going to have to retrench?

Aren't there too many Ph.D.'s being trained, and didn't I see something that indicates that we will not need to create so many $\mathrm{Ph}$.D.'s in the future? Therefore, can't we cut back on the materials needed to produce Ph.D.'s?

Shouldn't we charge for some of our services and try to produce supporting income?

I do not profess to have answers to these questions for the president, but I think they are likely to be very much in his mind and, therefore, specifically before us as we talk about the university library in the seventies.

I strongly urge that each of you imagines that your president is wrestling with the foregoing and related questions, and that he has just put his hand on his telephone to call you regarding these issues. Are you prepared to answer? Would it not be well to list such questions and others you are going to be asked, if you haven't already been asked, and get your closest colleagues to join you in thinking about the most effective replies?

For what it is worth, let me give you a note of encouragement. In the last year as a consultant I have been on more college and university campuses than I had visited during the previous three decades of my association with academia. I have yet to encounter a college president, chief fiscal officer, or chairman of a governing board who is planning to solve his fiscal problems at the expense of the library. This is not to say that library budgets will grow as they wish they might, but it is to emphasize that everyone I have talked to is at least giving convincing verbalization to the fact that the library is the basic core upon which the rest of the academic program always depends.

If your chief executives ask you some of the questions outlined above, you may want to remind them of the following theorems:

Deferred maintenance always leads either to (1) increased costs, (2) reduced scope or (3) decreased quality; It isn't a fact that every book and publication available today can just as easily and economically be acquired later on; and

If the campus is going to produce a single $\mathrm{Ph} . \mathrm{D}$. in a given discipline, the fact that fewer total Ph.D.'s are going to be conferred does not materially reduce library costs.

In the polemics which inevitably surround the process of budget making, there is no way to predict which argument will prove the most convincing or lead to the best results, but it can be averred with absolute certainty that if you neglect to develop the best possible answers to those questions which are put to you by your harassed chief executive, you will not fare as well as you ought to in the division of whatever there is to be divided. 


\section{New Modes of Organization AND ADMINISTRATION}

It does not take an organizational theorist to conclude that in recent years most of the organizations, particularly the major bureaucracies, in our society are in trouble. The structure of our government, our military, our churches, our corporations, and our educational institutions do not seem to be able to cope with many of the problems confronting them. One reason is that our organizational patterns and procedures are based on principles of hierarchy and obedience which simply do not work as well in colleges in 1971 as they did in churches in the fifth century. It is a fascinating anomaly that, in an organization made up of highly intellectual and rational men, some of the most archaic procedures and principles of organization are tolerated without question and correction. If you have any doubt as to the primitive nature of academia today, just contemplate-with heartfelt sympathythe information input overload which your chief executive must endure.

During the 1970 s we will see a great change in the structure of and procedures followed in higher education.

The organization will change from its traditional form to a much more viable and humane structure where lateral interchange is encouraged.

Governing boards will acknowledge and accept their more fundamental policy-making role and leave administration to the administrators.

Decision-making will grow out of a much broader base of consensus and will be much less secretive and arbitrary.

The campus radical and his sympathetic faculty supporter will adopt the posture of relentless gradualism rather than the role of violent disruption.

For more than 300 years, the basic structure of our universities and col- leges in this country has remained about the same. The decade of the $1970 \mathrm{~s}$ is likely to see many experiments and some lasting innovations in how we live together. This decade may witness a breakdown of departmental autonomy and of the artificial divisions we have established in the realm of man's knowledge. Within a few years we may witness the election of our chief executives on some pattern not unlike the British universities. What is wrong with the idea that no university president will be hired for more than a fixed term (say five years) after which his performance will be reviewed, and he might be subject to a reappointment for an additional term if his performance warrants it? I do not really know whether in 1979 our chief executives will be elected by their peers or chosen for a fixed term by the governing board, but I do know that the role of the president or the chancellor has become highly unmanageable, virtually untenable and little of the fun and reward which once existed in this job still remains. Therefore the role of the president (chancellor), the organization of top administration, and many of the procedures which we have lived with in the past are likely to change during this decade.

If I am right and these kinds of changes are imminent, it is imperative that the librarian analyze how he fits into this process of change and where he wants to come out when the dust settles. Here are some ideas we may want to argue about during the question period:

Should the campus librarian become a university-wide official at the second echelon? Why not establish the position of vice president for university libraries?

Shouldn't the governing board have a standing committee (or subcommittee) on libraries? Or at least shouldn't the board hear a presentation concerning 
the libraries at least once or twice each academic year?

Should not the university librarian, because of the universal impact his activities have on virtually every aspect of campus life, sit with the highest advisory body to the president?

A fair amount is being written these days about the symptoms, causes and treatment of neurotic organizations. The thesis is that organizations, like individuals, develop neuroses, and unless these matters are treated, the fundamental work for which the organization was originated suffers greatly. My point is that many of our institutions, including universities and colleges, have become neurotic and that pressures will be very great during the 1970s to change their organization and procedures in an attempt to correct these faults and make the institutions more capable of fulfilling their basic roles in modern society. The university librarian should consider this thesis with great care, and if he finds it to have merit he should plan the role he feels he ought to fulfill in a restructured university and work toward achievement of that goal. If the university librarian merely rides the reorganizational hurricane which I am predicting for the seventies, like a shuttlecock in a tempest, he could emerge in a less influential and effective position in the new structure than he holds in the present structure.

\section{NEW ROLES FOR THE LIBRARY AND THE LIBRARIAN}

Speculations about the proper administrative status of the librarian lead to questions about the role he should play during the seventies. As a starter, let me suggest that the librarian during this decade ought to become very much more of a planner than has traditionally been his inclination.

Planning is the orderly means used by an organization to establish effective con- trol over its own future. As you know, to be effective any plan you devise for the future of your library must be logical, comprehensive, flexible, action-oriented, and formal. Further, it must extend into the future and involve human resources. I give this definition and enumerate these elements not only for the record but to stress that it is your responsibility to engage in planning whether anyone else around the campus is doing so or not. During the 1960s, when growth was rampant, optimism was in the air and relative affluence existed, planning hardly seemed necessary (at least very few were seriously undertaking it). When an enterprise is burgeoning, the enthusiasm of growth seems to carry it on toward adequate handling of the challenges ahead. When the fiscal horizons are bleak and retrenchment is indicated, planning is crucial but much more difficult to accomplish. And the more difficult planning becomes, the more important it is for the creative executive to undertake this painful process. Accentuate your role therefore as a planner.

The librarian also should acknowledge his role as a fund raiser. (Are those sighs or groans I hear among you?) I am afraid it is inevitable that, just as surely as the president will single out the library for cost reduction opportunities, he will ask the librarian to assist in raising additional funds. His questions will include the following:

Can we charge something more for our services?

Can you organize a "friends of the library" or can you somehow stimulate additional memberships for an existing group?

The easiest response for you to make at this juncture is to insist that you are a librarian, not a fund raiser. But I urge you to consider another alternative. Although development officers will loudly proclaim an opposite view, there is noth- 
ing mysterious about the art of raising funds, but if you do not personally savor this activity, ask the president for a professional to help you. It is still true that if you provide a professional fund raiser with his administrative costs, 10 percent, 12 percent, or 15 percent, or stated otherwise, 10 cents, 12 cents, or 15 cents, he can raise for you a dollar. If he is a true professional he will stop asking for additional administrative pump-priming dollars if he concludes that they can't produce new benefactions. Unless you are serving an exceptional institution, your campus is in poor, difficult and, in some cases, dire financial straits. My recommendation is that instead of avoiding the responsibility for fund raising you reach for it and ask for the help you need if fund raising is not among your many skills.

Also become an innovator. Innovation always costs money and, therefore, may seem a little inconsistent with the points I have just made. However, innovation pursued by thoughtful and dedicated executives will increase effectiveness and decrease costs.

It seems clear to me that the current popularity of selfstudy programs, "universities without walls," and expanded adult education will greatly increase the requirements of the library. The tidal wave is coming and several of the subjects in the program of this meeting recognize its imminence. Can you not demonstrate to your president that timely preparation for the inevitable onslaught will prove economical in the end? In short, I am urging that you seize the initiative and point out where future shock is going to hit the library.

This is the decade of Educom, Edunet, communications satellites, facsimile transmission, and burgeoning opportunities for visual outreach. We are close to the time when thousands of students, hundreds of miles apart, will be able to listen to the most distinguished professor in a given field discuss the most recent innovations and his latest thoughts about them. By the end of the 1970 s we will surely have data transmission systems which will allow you to call up from a distant place a document needed by one of your users. Too expensive, your president may say, but can we not convince him that the costs of this equipment will be far less than building and maintaining adequate collections in every area your users may require?

Further, the librarian must remain flexible, and here I may be treading upon the thinnest ice yet encountered. I predict that you have on your staff many who are almost too rigid, meticulous, and precise. Indeed, these traits may have led them into the orderliness and symmetry of cataloging systems and the joys of collecting and arranging human knowledge. You would not have emerged as a qualified administrator if you had not been able to deal effectively with these tendencies in the staff. But I am urging that even greater flexibility among librarians may be called for in the future. Standing as you are at that point where so many forces converge, it may become necessary to accept many more compromises than have heretofore proved acceptable. You stand at that focus where financial pressures, increased user demands, vast expansion of printed materials and improved techniques of publishers and book salesmen converge. The delays in acquiring, cataloging, and shelving a book may not result from traditional and rigid practices but many administrators and users think so to the detriment of library budgets. A genuine effort by the library staff to evince flexibility and creativity will enhance performance and dispel the idea that libraries are suffering from administrative arthritis.

In summary, the decade of the 1970s will be a time of dramatic change in our fiscal lives, our organizations' structures and procedures and the roles which all of us, including librarians, will be ex- 
pected to play. To anticipate these changes and reflect on how to meet them is to go far toward solving the problems which are inescapable in the decade ahead.

Perhaps the greatest challenge facing any of us in the seventies is to keep constantly in mind the fundamental mission of the university. We become so caught up in program budgets, structure, procedures, personnel forms, requisitions, labor negotiations and hardware that we are tempted to lose sight of what the institution of higher education is all about. The idea that we are involved in the preservation, transmission, testing, augmentation, and application of human knowledge is so exciting that it makes the strains, anxieties, and frustrations seem worthwhile.

My remarks have been at times bleak and at times threatening. For my own psychic comfort, I would like to end with two quotations which underscore the importance of the university and of your work. The first is the brief statement of James Bryant Conant taken from his notes on the Harvard tercentenary: "He who enters a university walks on hallowed ground." The second are the words of Thomas Carlyle from his "The Hero as Man of Letters": "The true university of these days is a collection of books."

The 1970s will be difficult and frustrating years, but being a part of a university, you are directly involved with that entity which is likely to provide the best hope for mankind's growth, enrichment, and perhaps even his survival; and as both keepers and protectors of a man's knowledge, and as stimulators to its testing and use, you are at the very core of the university community. I wish you continued success in your vastly important undertaking. 